This is a self-archived version of an original article. This version may differ from the original in pagination and typographic details.

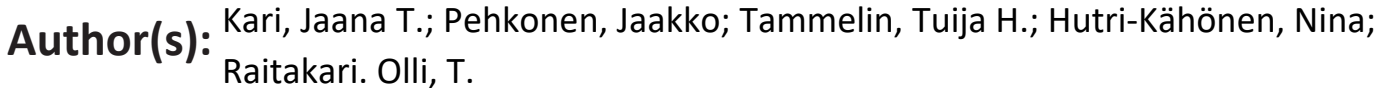

Title: Childhood physical activity as a labor market investment

Year: 2021

Version: Accepted version (Final draft)

Copyright: ㄷ 2020 John Wiley \& Sons A/S

Rights: In Copyright

Rights url: http://rightsstatements.org/page/lnC/1.0/?language=en

Please cite the original version:

Kari, J. T., Pehkonen, J., Tammelin, T. H., Hutri-Kähönen, N., \& Raitakari. Olli, T. (2021).

Childhood physical activity as a labor market investment. Scandinavian Journal of Medicine and Science in Sports, 31(1), 163-183. https://doi.org/10.1111/sms.13829 
DR JAANA T KARI (Orcid ID : 0000-0001-5205-7031)

Article type : Original Article

\section{Childhood physical activity as a labor market investment}

Running Head: Physical activity and labor market outcomes

Jaana T. Kari*1, Jaakko Pehkonen ${ }^{1}$, Tuija H. Tammelin², Nina Hutri-Kähönen ${ }^{3}$, Olli T.

Raitakari4,5,6

${ }^{1}$ Jyväskylä University School of Business and Economics, University of Jyväskylä, Jyväskylä, Finland

${ }^{2}$ LIKES Research Centre for Physical Activity and Health, Jyväskylä, Finland.

${ }^{3}$ Department of Pediatrics, Tampere University Hospital, Tampere, Finland.

${ }^{4}$ Research Centre of Applied and Preventive Cardiovascular Medicine, University of Turku, Turku, Finland

${ }^{5}$ Department of Clinical Physiology and Nuclear Medicine, Turku University Hospital, Turku, Finland.

${ }^{6}$ Centre for Population Health Research, University of Turku and Turku University Hospital, Turku Finland

Corresponding author: Jaana T. Kari (DSc (Econ.), jaana.t.kari@jyu.fi, Jyväskylä University School of Business and Economics, P.O. Box 35, FI-40014 University of Jyväskylä, Jyväskylä, Finland. Tel. +358406234336 .

This article has been accepted for publication and undergone full peer review but has not been through the copyediting, typesetting, pagination and proofreading process, which may lead to differences between this version and the Version of Record. Please cite this article as doi: $\underline{10.1111 / \text { SMS.13829 }}$

This article is protected by copyright. All rights reserved 


\section{Funding information}

This study was supported by the Finnish Ministry of Education and Culture, Juho Vainio Foundation, Yrjö Jahnsson Foundation (grants 6648, 6914, 6915), the Academy of Finland (grant 273971), and OP Group Research Foundation. The Young Finns Study has been financially supported by the Academy of Finland: grant numbers 322098, 286284, 134309 (Eye), 126925, 121584, 124282, 129378 (Salve), 117787 (Gendi), and 41071 (Skidi); the Social Insurance Institution of Finland; Competitive State Research Financing of the Expert Responsibility area of Kuopio; Tampere and Turku University Hospitals (grant number X51001); Juho Vainio Foundation; Paavo Nurmi Foundation; Finnish Foundation for Cardiovascular Research; Finnish Cultural Foundation; the Sigrid Juselius Foundation; Tampere Tuberculosis Foundation; Emil Aaltonen Foundation; Yrjö Jahnsson Foundation; Signe and Ane Gyllenberg Foundation; Jenny and Antti Wihuri Foundation; Diabetes Research Foundation of Finnish Diabetes Association; EU Horizon 2020 (grant number 755320 for TAX-INOMISIS); European Research Council (grant number 742927 for MULTIEPIGEN project); and Tampere University Hospital Supporting Foundation.

Conflict of interest: The authors declare no conflicts of interest. 


\section{Abstract}

This study examined the role of physical activity and changes in physical activity levels during childhood in long-term labor market outcomes. To address this important but under-researched theme, the study utilized data drawn from longitudinal research, the Cardiovascular Risk in Young Finns Study (YFS), and from registries compiled by Statistics Finland. The study consisted of children aged $9(n=1565)$ and $15(n=2445)$ at the time their physical activity was measured. Labor market outcomes, including employment status, average employment months, and average unemployment months, were calculated from 1997 to 2010, when the participants were aged 20 to 48 years. Regression models were used to assess the relationship between physical activity and labor market outcomes. The results show that the consequences of childhood physical activity may be far-reaching, as higher childhood physical activity was positively related to the probability of being employed and employment months and was negatively related to unemployment months. On average, a one-unit increase in physical activity index was related to a $1 \%$ higher probability of being employed, 0.10 more months of yearly employment, and 0.05 fewer months of yearly unemployment. The results also imply that persistently active individuals had the highest level of employment and the lowest level of unemployment compared with other activity groups. In conclusion, investments in childhood physical activity may not only promote health and wellbeing but may also correlate with better labor market outcomes later in life, providing both personal and societal benefits.

Keywords: Physical activity, Employment, Unemployment, Register-based data 


\section{Introduction}

In recent years, several studies have focused on the economic consequences of physical activity and inactivity. Globally, it is estimated that the direct costs attributable to physical inactivity range from $0.3 \%-4.6 \%$ of national healthcare expenditures. ${ }^{1,2}$ Additionally, studies in this field have found that physical activity is related to indirect rewards in the labor market, such as higher earnings $^{3-11}$ and higher probability of employment ${ }^{8,12,13}$ (see Appendix 1 for a literature summary).

Using cross-sectional data from 25 European countries, Kavetsos, ${ }^{13}$ for example, showed that physically active adults are more likely to be employed, and Lechner and Downward ${ }^{8}$ documented a negative association between sports participation and unemployment. Cabane ${ }^{12}$ further showed that physical activity in adulthood is related to a quicker transition from unemployment to employment, especially among women. The findings by Rooth ${ }^{10}$ and Lechner ${ }^{7}$ suggest that cardiovascular fitness ${ }^{10}$ and physical activity ${ }^{7}$ are positively associated with earnings among both men and women. Rooth ${ }^{10}$ also showed that individuals who indicate in job applications that they are physically active have a higher probability of receiving callbacks to job interviews. Cabane and Clark $^{24}$ and Kari et al. ${ }^{5}$ are examples of studies that have analyzed the role of childhood physical activity instead of adulthood physical activity in various labor market outcomes. In sum, Cabane and Clark $^{24}$ did not find an association between childhood sporting activities and earnings, job satisfaction, and the probability of being a worker, whereas Kari et al., ${ }^{5}$ on the other hand, did document a positive association between childhood leisure-time physical activity and earnings in adulthood, especially among men.

Despite these valuable studies, little is known about the longitudinal associations between physical activity in childhood and labor market outcomes in adulthood. An important limitation of the existing literature is the lack of longitudinal data regarding both physical activity and labor market outcomes. In particular, most prior studies have focused on physical activity in adulthood only and have used self-reported labor market data. This raises two concerns. First, labor market outcomes themselves may be related to physical activity, ${ }^{4,14,15}$ raising potential problem of reverse causality. Second, self-reported and cross-sectional information on labor market outcomes are prone to measurement error, which may yield inaccurate estimates. 
This study addressed these concerns by utilizing data drawn from administrative registries and investigating the role of childhood physical activity and changes in physical activity levels during childhood in long-term labor market outcomes. Specifically, the study answered the following question: Can childhood physical activity or changes in physical activity from childhood to youth explain persistent differences in individuals' employment probability, employment months, and unemployment months? We hypothesize that higher physical activity in childhood is related to higher employment and lower unemployment in adulthood. If the results are as hypothesized, then investing in programs that foster children's participation in physical activity would be justified. This could further encourage the young toward higher levels of physical activity, and improve their labor market returns later in life, providing both personal and societal benefits.

\section{Materials and methods}

\subsection{Study population}

The data were drawn from three Finnish datasets covering the 1980-2010 period: (1) the ongoing longitudinal Cardiovascular Risk in Young Finns Study (YFS); (2) the Finnish Longitudinal Employer-Employee Data (FLEED) of Statistics Finland; and (3) the Longitudinal Population Census (LPC) of Statistics Finland. All participants of the YFS provided written informed consent, and the study was approved by the local ethics committees (The Ethics Committee of the Hospital District of Southwest Finland). Parents or guardians provided written informed consent on behalf of the under-aged children enrolled in the study. The final linked YFS-FLEED-LPC data have been approved for research purposes by Statistics Finland (Permission TK-53-673-13) under the ethical guidelines of the institution, which comply with national standards.

YFS was launched in the late 1970 s to study cardiovascular risk in adolescence. ${ }^{16}$ In 1980,3596 children aged 3, 6, 9, 12, 15, and 18 years participated in the baseline study. The participants were boys (51\%) and girls (49\%) randomly selected from five Finnish communities. Since 1980, seven follow-ups have been conducted, with the latest in 2011/2012. Each follow-up has included comprehensive methods for data collection, including questionnaires, physical measurements, and blood tests. ${ }^{16}$

FLEED is an annual panel comprising the entire working-age population of Finland. It records detailed information on labor market outcomes, such as employment relationships, unemployment 
periods, and income. The data derive directly from tax and other administrative registers and are maintained by Statistics Finland. Information on family background factors from 1980 (parental education and family income) were drawn from the register-based LPC. The YFS, FLEED, and LPC data were linked using unique, personal identifiers. This process involves exact matching, without misreported ID codes, and avoids problems created by errors in record linkages. Moreover, labor market details do not suffer under-reporting, over-reporting, or recall errors. Combining the data sets enabled the tracking of individuals who participated in the YFS in the baseline year from childhood to adulthood (Appendix 2).

\subsection{Register-based labor market outcomes}

Individuals' labor market outcomes were measured with three variables: (1) employment status, (2) employment months, and (3) unemployment months. Employment status was formulated as a binary variable that equaled 1 if an individual was employed throughout the observational year, and 0 otherwise (unemployed, retired, or outside labor force). Employment months referred to the average number of employment months per year over the 1997-2010 and 2005-2010 periods, while unemployment months referred to the average number of unemployment months per year over the same periods. The period from 1997 to 2010 covered the entire working history of the YFS participants, whereas the period from 2005 to 2010 covered the prime working age as the mean age of the YFS participants varied from 28 to 45 years.

\subsection{Self-reported physical activity}

Leisure-time physical activity levels outside school hours at ages 9 and 15 years were measured with a self-reported questionnaire. From 1980 to 1989, the questions concerned the frequency and intensity of leisure-time physical activity, participation in sports club training sessions, participation in sports competitions, and the most common ways of spending leisure-time (Appendix 3). ${ }^{17,18}$ In 1992, the questions concerned the intensity of leisure time physical activity, the frequency of intensive physical activity, hours per week of intensive physical activity, average duration of physical activity sessions, and membership in a sports club (Appendix 4). ${ }^{17,18}$ The response alternatives were coded 1, 2, or 3-except participation in a sports club, which was coded 1 or 2 - and then summed to yield a physical activity index (PAI) with scores ranging from 5 (lowest physical activity level) to 14 (highest physical activity level). 
To illustrate changes in physical activity levels between ages 9 and 15, participants were classified into five activity groups: (1) persistently active, (2) increasingly active, (3) moderately active, (4) decreasingly active, and (5) persistently inactive. This was done by first dividing the participants into three activity groups according to their PAI values at age 9: physically active (PAI $\geq 11$ ), moderately active (PAI=9-10), and physically inactive (PAI $\leq 8)$. Thereafter, at age 15, participants were classified into five activity groups: persistently active had PAI values of $\geq 11$ at both ages. Increasingly active involved increased physical activity levels, from "physically inactive" to "moderately active" or "physically active," or from "moderately active" to "physically active," between ages 9 and 15. Moderately active had PAI values of 9-10 at both ages. Decreasingly active involved decreased physical activity levels, from "physically active" to "moderately active" or "physically inactive," or from "moderately active" to "physically inactive", with persistently inactive having PAI values of $\leq 8$ at both ages.

\subsection{Statistical analysis}

The empirical analysis focused on the YFS participants who were aged $9(n=1565)$ and 15 $(n=2445)$ at the time physical activity was measured. Table 1 provides the mean characteristics of the samples.

$<$ Table 1 here $>$

The analysis was based on the ordinary least squares (OLS) model, in which the associations between physical activity and labor market outcomes were regressed using the average employment months and the average unemployment months as the dependent variables and the PAI at the ages of 9 and 15 years as explanatory variables. The baseline models included only exogenous and predetermined controls: gender, birth cohort, and birth month. The baseline analysis was extended in three ways.

First, the robustness of the results was evaluated by adjusting the models with variables that could confound the labor market-physical activity association - that is, the models were adjusted to account for factors such as chronic diseases, body fat, family income, family size, and parents' education in 1980. To prevent reverse causality, all control variables were obtained before labor 
market experience. Second, boys and girls may prefer different types of physical activity and, accordingly, their working paths may differ. ${ }^{19}$ To examine potential gender heterogeneity, the models were stratified by gender. Lastly, overall physical activity levels and sports participation typically decrease during childhood and youth. ${ }^{20-22}$ A similar trend can be seen in YFS data: 33\% of children are decreasingly active between the ages of 9 and 15 (Table 1), whereas the percentage of children between ages 9 and 15 who are increasingly active is $22 \%$. To examine whether these changes are related to average employment and unemployment months, the analysis was extended using the activity groups as explanatory variables. Before the OLS models were generated, the association between childhood physical activity and the probability of employment was illustrated with a probit model.

\section{Results}

\subsection{Probability of being employed}

Table 2 reports the probit results of childhood physical activity and adulthood employability. On average, an increase in PAI at ages 9 and 15 increased the predicted probability of employment over the 1997-2010 and 2005-2010 sample periods. On average, a one-unit increase in PAI at ages 9 and 15 was related to a $1 \%$ higher probability of being employed during the years 20052010 .

$<$ Table 2 here $>$

\subsection{OLS results}

The OLS results reported in Table 3 suggest a positive association between PAI and employment months and a negative association between PAI and unemployment months. On average, a oneunit increase in PAI at ages 9 and 15 was associated with approximately 0.11 (3 days) and 0.08 (2 days) more months of yearly employment, respectively. This one-unit increase in PAI can be reached if one of the following alternatives occurs: (1) the frequency of leisure-time physical activity lasting at least 30 minutes increases from "once a month" to "once a week," (2) the amount of weekly intensive activity increases from "1 hour a week" to "2-3 hours a week," or (3) the frequency of participating in sports club training sessions increases from "less than once a month" to "once a month or more" or "once a week" (Appendices 3 and 4). Regarding unemployment, a one-unit increase in PAI at ages 9 and 15 was associated with approximately 
0.05 ( 2 days) and 0.08 ( 2 days) fewer months of yearly unemployment, respectively. The results were robust to the inclusion of control variables as well as to the time period used.

$<$ Table 3 here $>$

\subsection{Gender differences}

When the models were stratified by gender (Table 4), the results indicated a positive association between PAI and employment months and a negative association between PAI and unemployment months among men. On average, a one-unit increase in PAI at ages 9 and 15 was associated with approximately 0.18 (5 days) and 0.10 (3 days) more months of yearly employment, respectively. The results remained intact regardless of the period used. Among women, in contrast, no association between childhood PAI and employment months was found. Instead, PAI at 15 years was negatively related to unemployment months. A one-unit increase in PAI at 15 years was related to approximately 0.07 fewer months ( 2 days) of yearly unemployment.

$<$ Table 4 here $>$

\subsection{Changes in physical activity level}

Table 5 presents descriptive statistics regarding the relationship between changes in physical activity levels from 9 to 15 years of age in terms of average employment and unemployment months. The results suggest that individuals classified as persistently active had more employment months and fewer unemployment months than did individuals categorized in the other activity groups.

$<$ Table 5 here $>$

Figures 1 and 2 depict the average yearly employment and unemployment months by activity group from 2005 to 2010 (for 1997-2010, see Appendices 5 and 6). The descriptive evidence suggests that labor market attachment is more favorable among the persistently active, also on a yearly basis. More specifically, from 2005 to 2010, persistently active individuals had, on average, more employment months in each year than did the other activity groups (Figure 1), for which the average employment months were relatively similar. Regarding unemployment (Figure 2), the 
yearly level was lowest among persistently active individuals. Interestingly, even after the financial crisis in 2008, the trend has been increasing among persistently active individuals, whereas persistently inactive individuals have experienced a downward sloping trend (Figure 1). Figure 2 also displays a certain order among the other activity groups. For instance, in 2010, persistently inactive individuals had the highest level of unemployment, decreasingly active the second highest, with moderately active in the middle; whereas increasingly active individuals had the second lowest level of unemployment, and persistently active had the lowest.

$<$ Figures 1 and 2 here $>$

Table 6 gives estimates regarding the relationship between activity groups and long-term (un)employment. Compared with the persistently active group, all other activity groups had lower employment and higher unemployment. On average, between 1997 and 2010, persistently inactive individuals had approximately 0.8 fewer months ( 24 days) of employment and 0.6 more months (18 days) of unemployment each year than their persistently active counterparts. The results remained intact to the inclusion of control variables (Table 6, Model 2) as well as to the time period used.

$<$ Table 6 here $>$

\section{Discussion}

\subsection{Summary of the results}

This study examined the relationship between childhood physical activity and long-term labor market outcomes with a focus on employment and unemployment. The data were drawn from longitudinal research, the YFS, linked to administrative data from Statistics Finland. Two main findings emerged from the study. First, childhood physical activity is positively related to the probability of being employed and employment months, and negatively related to unemployment months. Second, persistently active children at ages 9 and 15 have, on average, the highest level of employment and the lowest level of unemployment each year compared with other activity groups. 
The literature investigating the role of childhood leisure-time physical activity in labor market outcomes in adulthood is limited, with studies focusing mostly on the effects of adult physical activity. 4,7,12,13,23 To our knowledge, only two studies have examined the role of childhood leisuretime physical activity on labor market outcomes. ${ }^{5,24}$ Contrary to our results, Cabane and Clark ${ }^{24}$ did not find an association between childhood sporting activities and employment. Instead, their results suggested that childhood sporting activities predicted managerial responsibilities and autonomy at work. Kari et al., 5 in turn, focused on earnings, with the results suggesting a positive association between childhood physical activity and long-term earnings, especially among men. Therefore, the findings of the present study may explain the findings documented by Kari et al. ${ }^{5}$; childhood physical activity is related to higher employment and lower unemployment, which, in turn, may yield higher earnings.

\subsection{Limitations and strengths}

First, the results did not provide direct evidence of causality between childhood physical activity and labor market outcomes. As prior literature has suggested, there are many potential pathways through which physical activity may affect later-life outcomes in the labor market. Physical activity is related to health improvements, ${ }^{25,26}$ which may lead to better worker performance, thereby increasing labor productivity and earnings. ${ }^{7,27}$ Physical activity may also facilitate social and professional networks, which promote career development and increase labor market returns. ${ }^{7}$ Additionally, physical activity may develop cognitive ${ }^{28-30}$ and non-cognitive skills, ${ }^{31-33}$ which are rewarded later on in the labor market. Employers may also perceive that physically active individuals are in good health and have stronger motivations, ambitions, and productivity, resulting in positive discrimination in the labor market. ${ }^{10}$

The association may, however, also be spurious, stemming from unobserved factors that simultaneously affect childhood physical activity and adulthood labor market outcomes. For instance, children of highly educated parents may be encouraged to be physically active, or they may have more opportunities to invest in physical activity. Simultaneously, whether via nature or nurture, children of highly educated parents may obtain higher labor market returns once they become adults. Thus, the findings documented in this study might have occurred regardless of participation in physical activity as a child. Other possible explanations include an individual's health, innate ability, or personality. Although an individual's health endowments and family 
background factors, including family income and parents' education were accounted for, a wide range of unobserved factors may remain. To explore the potential mechanisms behind the findings of this study, future studies need larger sample sizes and informative data sets covering, for example, health endowments, personality, and cognitive ability. As well, larger sample sizes with informative data sets would also enable future studies to utilize identification strategies that could shed light on the causality between childhood physical activity and adulthood labor market outcomes. An example of these estimation strategies is a propensity score matching (PSM) estimation, as conducted in the studies by Lechner ${ }^{7}$ and Lechner and Downward. ${ }^{8}$ Following Lechner $^{7}$ and Lechner and Downward, ${ }^{8}$ we tested a PSM estimation, with the results corresponding to the baseline OLS results (Appendix 7). However, the results were based on a small sample sizes and as such should be interpreted with caution.

Second, the association between PAI and employment months was significant only among men, while the association between physical activity and unemployment months was significant among both men and women. The specificity of women's career paths, especially women of childbearing age, is an issue that must be considered when interpreting the results. The age range of the study sample varied from 20 to 45 . Thus, women's choices regarding childbearing and how these choices impact their labor market outcomes are important for understanding the study results. This specificity may lead to a more complex labor supply and occupational choices among women compared to men of the same age. However, the gender-specific results were based on relatively small sample sizes and might therefore have been sensitive to subsampling. This may have produced biased estimates, and thus these results should be interpreted with caution as well. Additionally, due to the small sample size, we were unable to analyze the gender-specific role of changes in physical activity levels in employment and unemployment. Therefore, by using larger sample sizes, future studies could illuminate these potential gender differences.

The linked data and the longitudinal study design contribute to and extend the previous literature in four important ways. First, as earlier studies have suggested, physical activity in adulthood can be partly explained by individuals' economic resources. ${ }^{4,14,15}$ This can make the direction of the causality between physical activity and labor market outcomes unclear. Focusing on childhood physical activity measured before any labor market experience eliminates the potential problem of reverse causality. To consider changes in physical activity from childhood to adulthood, the 
models were extended by adulthood physical activity. As a result, the point estimates for childhood PAI remained largely intact (Appendix 8). This finding suggests that the relationship between childhood physical activity and long-term labor market outcomes exists irrespective of changes in physical activity throughout life.

Second, to mitigate the concern of idiosyncratic fluctuations related to short-term measures, the labor market details were calculated over the 1997-2010 and 2005-2010 periods. The former period constituted the entire working history of the YFS participants, whereas the latter period focused on the prime working age of the YFS participants. Additionally, the labor market details were obtained from registers maintained by Statistics Finland, and therefore potential biases resulting from self-reported information were avoided. Third, to alleviate the possibility that unobserved characteristics, such as pre-existing differences in individuals' health and family background factors, drove the results, the models were extended with individuals' chronic conditions, body fat, family income, family size, and parents' education. As a result, the results remained intact.

Lastly, the impact of physical activity on labor market outcomes may take time to materialize. ${ }^{7}$ The longitudinal study design and the inclusion of childhood physical activity details combined with longitudinal labor market information enabled us to address this problem. We were able to show that the consequences of childhood physical activity on labor market outcomes start developing as early as childhood, that differences in labor market outcomes are present already at the beginning of the working career (Appendix 6), and that differences in long-term labor market outcomes can be explained by childhood physical activity.

\section{Perspective}

We believe that the findings of the present study can be generalized to other developed European countries. This is because physical activity behavior and labor market participation are relatively similar among Europeans, employment rates are high across European countries, and Europeans have broadly similar labor market institutions. ${ }^{34}$ As in many other countries, in Finland, physical activity levels are low among children. ${ }^{35-39}$ Along with the widely acknowledged health benefits of physical activity, ${ }^{25,26,40}$ this study recognized childhood physical activity as a correlate of labor market success; the consequences of childhood physical activity on subsequent labor market 
outcomes may begin to develop as early as childhood. Thus, childhood physical activity not only promotes health but may also contribute positively to labor market outcomes later in life. From a policy perspective, these findings support investing in programs aimed at promoting children's participation in physical activity. Although the focus in the present study was on childhood leisure-time physical activity outside school hours, we believe that the school setting could be an essential arena to reach all children and thereby has the potential to impact the development of children's physical activity behavior. By doing so, young people could be motivated to pursue more physically active lifestyles in childhood and beyond, thereby potentially improving their health and labor market returns once they become adults, generating both personal and societal benefits. 


\section{References}

1. Ding D, Kolbe-Alexander T, Nguyen B, et al. The economic burden of physical inactivity: a systematic review and critical appraisal. Br J Sports Med 2017;51(19):1392-1409. doi:10.1136/bjsports-2016-097385

2. Ding D, Lawson KD, Kolbe-Alexander TL, et al. The economic burden of physical inactivity: a global analysis of major non-communicable diseases. Lancet 2016;388(10051):1311-1324. doi:10.1016/S0140-6736(16)30383

3. Cabane C. Do Sporty People Have Access to Higher Job Quality? SOEP Papers on Multidisciplinary Panel Data Research 308. DIW Berlin, The German Socio-Economic Panel (SOEP).

4. Hyytinen A, Lahtonen J. The effect of physical activity on long-term income. Soc Sci Med 2013;96:129-137. doi:10.1016/j.socscimed.2013.07.019

5. Kari JT, Tammelin TH, Viinikainen J, et al. Childhood physical activity and adulthood earnings. Med Sci Sport Exerc 2016;48(7):1340-1346. doi:10.1249/MSS.0000000000000895

6. Kosteas VD. The effect of exercise on earnings: evidence from the NLSY. J Labor Res 2012;33(2):225-250. doi:10.1007/s12122-011-9129-2

7. Lechner M. Long-run labour market and health effects of individual sports activities. $J$ Health Econ 2009;28(4):839-854. doi:10.1016/j.jhealeco.2009.05.003

8. Lechner M, Downward P. Heterogeneous sports participation and labour market outcomes in England. Appl Econ 2017;49(4):335-348. doi:10.1080/00036846.2016.1197369

9. Long JE, Caudill SB. The impact of participation in intercollegiate athletics on income and graduation. Rev Econ Stat 1991;73(3):525-531. http://www.jstor.org/stable/2109580.

10. Rooth DO. Work out or out of work - the labor market return to physical fitness and leisure sports activities. Labour Econ 2011;18:399-409. doi:10.1016/j.labeco.2010.11.006

11. Stevenson B. Beyond the classroom: using Title IX to measure the return to high school sports. Rev Econ Stat 2010;92(2):284-301. doi:10.3386/w15728

12. Cabane C. Unemployment duration and sport participation. Int J Sport Fin, Fitness Information Technology 2015;9(3):261-280.

13. Kavetsos G. The impact of physical activity on employment. J Socio Econ 2011;40:775- 
779. doi:10.1016/j.socec.2011.08.011

14. Kari JT, Pehkonen J, Hirvensalo M, et al. Income and physical activity among adults: evidence from self-reported and pedometer-based physical activity measurements. PLoS One 2015;10(8). doi:10.1371/journal.pone.0135651

15. Meltzer DO, Jena AB. The economics of intense exercise. J Health Econ 2010;29:347-352. doi:10.1016/j.jhealeco.2010.03.005

16. Raitakari OT, Juonala M, Rönnemaa T, et al. Cohort profile: the cardiovascular risk in young Finns study. Int J Epidemiol 2008;37(6):1220-1226. doi:10.1093/ije/dym225

17. Telama R, Leskinen E, Yang X. Stability of habitual physical activity and sport participation: a longitudinal tracking study. Scund J Med Sci Sport 1996;6(6):371-378.

18. Telama R, Yang X, Leskinen E, et al. Tracking of physical activity from early childhood through youth into adulthood. Med Sci Sports Exerc 2014;46(5):955-962. doi:10.1249/MSS.0000000000000181

19. Vilhjalmsson R, Kristjansdottir G. Gender differences in physical activity in older children and adolescents: the central role of organized sport. Soc Sci Med 2003;56(2):363-374. doi:10.1016/S0277-9536(02)00042-4

20. Nader PR, Bradley RH, Houts RM, et al. Moderate-to-vigorous physical activity from ages 9 to 15 years. JAMA 2008;300(3):295-305.

21. Tomkinson GR, Olds TS. Secular changes in pediatric aerobic fitness test performance: the global picture. Med Sci Sports Exerc 2007;50:44-466. doi:10.1159/000101075

22. Inchley J, Currie D, Young $\mathrm{T}$, et al. Growing Up Unequal: Gender and Socioeconomic Differences in Young People's Health and Well-Being. HBSC International Report from 2013/2014 Survey. WHO Policy for Children and Adolescents. No. 7. Copenhagen, WHO Regional Office for Europe 2016.

23. Lechner M, Sari N. Labor market effects of sports and exercise: evidence from Canadian panel data. Labour Econ 2014;35:1-15. doi:10.1016/j.labeco.2015.04.001

24. Cabane C, Clark AE. Childhood sporting activities and adult labour-market outcomes. Ann Econ Stat 2015;119-20:123-148. doi:10.15609/annaeconstat2009.119-120.123

25. Lee I-M, Shiroma EJ, Lobelo F, et al. Effect of physical inactivity on major noncommunicable diseases worldwide: an analysis of burden of disease and life expectancy. Lancet 2012;380(9838):219-229. doi:10.1016/S0140-6736(12)61031-9

26. World Health Organization. Global Status Report on Noncommunicable Diseases, 2014. 
http://apps.who.int/iris/bitstream/10665/148114/1/9789241564854_eng.pdf?ua=1 .

27. Lechner M. Sports, exercise, and labor market outcomes. IZA World of Labor 2015. doi:10.15185/izawol.126

28. Aberg MAI, Pedersen NL, Torén K, et al. Cardiovascular fitness is associated with cognition in young adulthood. PNAS 2009;106(49):20906-20911. doi:10.1073/pnas.0905307106

29. Barron JM, Ewing BT, Waddell GR. The effects of high school athletic participation on education and labor market outcomes. Rev Econ Stat 2000;82(3):409-421. doi:10.1162/003465300558902

30. Kari JT, Pehkonen J, Hutri-Kähönen N, et al. Longitudinal associations between physical activity and educational outcomes. Med Sci Sports Exerc 2017;49(11):2158-2166. doi:10.1249/MSS.0000000000001351

31. Ewing BT. Athletes and work. Econ Lett 1998;59:113-117. doi:10.1016/S01651765(98)00006-8

32. Bailey R. Evaluating the relationship between physical education, sport and social inclusion. Educ Rev 2005;57(1):71-90. doi:10.1080/0013191042000274196

33. Bailey R, Armour K, Kirk D, et al. The educational benefits claimed for physical education and school sport: an academic review. Res Pap Educ 2009;24(1):1-27. doi:10.1080/02671520701809817

34. Organisation for Economic Co-operation and Development. OECD Employment Outlook 2019: The Future of Work. OECD Publishing Paris, 2019. https://doi.org/10.1787/9ee00155-en.

35. Ekelund U, Tomkinson GR, Armstrong N. What proportion of youth are physically active? Measurement issues, levels and recent time trends. Br J Sports Med 2011;45(11):859-865. doi:10.1136/bjsports-2011-090190

36. Hallal PC, Andersen LB, Bull FC, et al. Global physical activity levels: surveillance progress, pitfalls, and prospects. Lancet 2012;380(9838):247-257. doi:10.1016/S01406736(12)60646-1

37. World Health Organization. Global Recommendations on Physical Activity for Health, 2010.

http://apps.who.int/iris/bitstream/handle/10665/44399/9789241599979_eng.pdf?sequence= 1. 
38. Aubert S, Barnes JD, Aguilar-Farias N, et al. Report card grades on the physical activity of children and youth comparing 30 very high Human Development Index countries. $J$ Phys Act Heal 2018;15(Suppl 2):S298-S314. doi:10.1123/jpah.2018-0431

39. Kämppi K, Aira A, Halme N, et al. Results from Finland's 2018 Report Card on Physical Activity for Children and Youth. $J$ Phys Act Health 2018;15(S2):S355-S356. doi:10.1123/jpah.2018-0510

40. 2018 Physical Activity Guidelines Advisory Committee. 2018 Physical Activity Guidelines Advisory Committee Scientific Report. Washington, DC 2018. 
Appendix 1. Summary of the literature

\begin{tabular}{|c|c|c|c|c|c|}
\hline $\begin{array}{l}\text { Author(s) and } \\
\text { publication year }\end{array}$ & Data & $\begin{array}{l}\text { Labor Market } \\
\text { Outcome }\end{array}$ & Physical activity measure & Methods & Main findings \\
\hline $\begin{array}{l}\text { Long and } \\
\text { Caudill (1991) }\end{array}$ & $\begin{array}{l}\text { Continuing study of } \\
\text { higher education by the } \\
\text { American Council of } \\
\text { Education }\end{array}$ & Annual income & $\begin{array}{l}\text { Dummy variable for } \\
\text { athlete. Equaled one if } \\
\text { varsity letter was earned in } \\
\text { college and zero otherwise. }\end{array}$ & MLE & $\begin{array}{l}\text { Athletic participation was positively } \\
\text { related to annual income in men. No } \\
\text { income premium was found among } \\
\text { women. }\end{array}$ \\
\hline $\begin{array}{l}\text { Eide and Ronan } \\
\text { (2001) }\end{array}$ & $\begin{array}{l}\text { High School and Beyond } \\
\text { data set (National Center } \\
\text { for Education Statistics) }\end{array}$ & Annual earnings & $\begin{array}{l}\text { Dummy variable for sports } \\
\text { participation in the } \\
\text { sophomore year and in the } \\
\text { senior year. Equaled one if } \\
\text { the respondent participated }\end{array}$ & OLS, IV & $\begin{array}{l}\text { A positive effect on earnings was } \\
\text { found among black men athletes. } \\
\text { No effect on earnings among } \\
\text { Hispanic men or Black and } \\
\text { Hispanic women was found. }\end{array}$ \\
\hline
\end{tabular}

This article is protected by copyright. All rights reserved 


\section{and zero otherwise.}

\begin{tabular}{|c|c|c|c|c|c|}
\hline Lechner (2009) & $\begin{array}{l}\text { German Socio-Economic } \\
\text { Panel study 1984-2006 }\end{array}$ & $\begin{array}{l}\text { Monthly } \\
\text { earnings, } \\
\text { accumulated } \\
\text { average } \\
\text { earnings, wage, } \\
\text { and employment } \\
\text { status }\end{array}$ & $\begin{array}{l}\text { Frequency of sports } \\
\text { participation divided into } \\
\text { two levels: being active at } \\
\text { least monthly and being } \\
\text { active less than monthly. }\end{array}$ & $\begin{array}{l}\text { Semiparametric } \\
\text { Propensity Score } \\
\text { Matching (SPM) }\end{array}$ & $\begin{array}{l}\text { Positive effect on earnings and } \\
\text { wages among women and men. An } \\
\text { increase in the probability of full- } \\
\text { time employment corresponded } \\
\text { with a decline in the share of } \\
\text { women considered as being out of } \\
\text { the labor force. }\end{array}$ \\
\hline Cabane (2010) & $\begin{array}{l}\text { German Socio Economic } \\
\text { Panel Data }\end{array}$ & $\begin{array}{l}\text { Hourly wage and } \\
\text { the level of } \\
\text { autonomy at } \\
\text { work }\end{array}$ & $\begin{array}{l}\text { A dummy variable sporty } \\
\text { corresponded to "practicing } \\
\text { sports at least once a week". }\end{array}$ & $\begin{array}{l}\text { OLS, Probit model; } \\
\text { only men included } \\
\text { in the analysis. }\end{array}$ & $\begin{array}{l}\text { Practicing sports was positively } \\
\text { associated with hourly wage and level } \\
\text { of autonomy. }\end{array}$ \\
\hline Kosteas (2011) & National Longitudinal & Supervisory & High school sports club & Household fixed & Positive association between club \\
\hline
\end{tabular}

This article is protected by copyright. All rights reserved 


\begin{tabular}{|c|c|c|c|c|c|}
\hline & Surveys of Youth, 1979 & $\begin{array}{l}\text { status and } \\
\text { responsibilities }\end{array}$ & participation. & effect (HFE), IV & $\begin{array}{l}\text { participation and being a supervisor } \\
\text { was found. }\end{array}$ \\
\hline Kavetsos (2011) & $\begin{array}{l}\text { Eurobarometer 2004, wave } \\
62\end{array}$ & Employment & $\begin{array}{l}\text { Frequency of physical } \\
\text { activity. }\end{array}$ & Probit model, IV & $\begin{array}{l}\text { Physical activity increased the } \\
\text { probability of being employed }\end{array}$ \\
\hline Rooth (2011) & $\begin{array}{l}\text { Integrated registers from } \\
\text { Statistics Sweden, Swedish } \\
\text { National Service } \\
\text { Administration, selected } \\
\text { occupations } \\
\text { found on the webpage of } \\
\text { the Swedish employment } \\
\text { agency }\end{array}$ & $\begin{array}{l}\text { Annual earnings } \\
\text { and call-backs } \\
\text { for job } \\
\text { interviews }\end{array}$ & $\begin{array}{l}\text { Cardiovascular fitness, } \\
\text { signalling physical activities } \\
\text { in a job application. }\end{array}$ & $\begin{array}{l}\text { Sibling fixed effects } \\
\text { model, Probit model }\end{array}$ & $\begin{array}{l}\text { Cardiovascular fitness was positively } \\
\text { associated with earnings. Signalling } \\
\text { participation in physical activity in a } \\
\text { job application was related to a higher } \\
\text { probability of receiving a call back } \\
\text { for a job interview. }\end{array}$ \\
\hline Kosteas (2012) & $\begin{array}{l}\text { National Longitudinal } \\
\text { Surveys } \\
\text { of Youth, } 1979\end{array}$ & Weekly earnings & $\begin{array}{l}\text { Frequency of vigorous } \\
\text { physical activity was divided } \\
\text { into four categories: rarely } \\
\text { exercise (less than once a } \\
\text { month), infrequent exercise } \\
\text { (1-3 times each month), } \\
\text { moderate exercise (1-2 times } \\
\text { per week), and frequent } \\
\text { exercise ( } 3 \text { or more times per } \\
\text { week). }\end{array}$ & $\begin{array}{l}\text { Propensity Score } \\
\text { Matching (PSM), } \\
\text { OLS, FE }\end{array}$ & $\begin{array}{l}\text { Physical activity was positively } \\
\text { associated with wages. }\end{array}$ \\
\hline $\begin{array}{l}\text { Cabane and } \\
\text { Clark (2013) }\end{array}$ & $\begin{array}{l}\text { National Longitudinal } \\
\text { Study of Adolescent Health }\end{array}$ & $\begin{array}{l}\text { Having } \\
\text { a paid job for at }\end{array}$ & $\begin{array}{l}\text { The type and the frequency } \\
\text { of sports. }\end{array}$ & $\begin{array}{l}\text { OLS with school } \\
\text { fixed effect, within- }\end{array}$ & $\begin{array}{l}\text { Childhood sporting activities were } \\
\text { associated with the level of autonomy }\end{array}$ \\
\hline
\end{tabular}

This article is protected by copyright. All rights reserved 


\begin{tabular}{|c|c|c|c|c|c|}
\hline & & $\begin{array}{l}\text { least } 10 \text { hours } \\
\text { per week, job } \\
\text { satisfaction, } \\
\text { managerial } \\
\text { responsibilities, } \\
\text { freedom to make } \\
\text { important } \\
\text { decisions, and } \\
\text { annual earnings }\end{array}$ & & sibling estimation & $\begin{array}{l}\text { and managerial responsibilities. No } \\
\text { association between sports and the } \\
\text { probability of being a worker, job } \\
\text { satisfaction, or earnings was found. }\end{array}$ \\
\hline Cabane (2014) & $\begin{array}{l}\text { German Socio Economic } \\
\text { Panel Data }\end{array}$ & $\begin{array}{l}\text { Unemployment } \\
\text { duration }\end{array}$ & $\begin{array}{l}\text { Frequency of practicing } \\
\text { sports divided into three } \\
\text { groups: sporty, not sporty, } \\
\text { and inactive. }\end{array}$ & Survival analysis & $\begin{array}{l}\text { Sports participation was related to a } \\
\text { quicker exit from unemployment to } \\
\text { employment for specific subsamples } \\
\text { (inactive, not sporty). }\end{array}$ \\
\hline $\begin{array}{l}\text { Hyytinen and } \\
\text { Lahtonen (2013) }\end{array}$ & $\begin{array}{l}\text { Older Finnish Twin Cohort } \\
\text { Study }(1975,1981,1990), \\
\text { Finnish Longitudinal } \\
\text { Employer-Employee Data }\end{array}$ & Annual income & $\begin{array}{l}\text { Three category dummies for } \\
\text { physical activity: } \\
\text { conditioning exercisers } \\
\text { (exercised at least } 6 \text { times } \\
\text { per month), sedentary } \\
\text { exercisers (did not partake } \\
\text { leisure-time physical } \\
\text { activity), and occasional } \\
\text { exercisers (all the others). }\end{array}$ & $\begin{array}{l}\text { OLS, within MZ } \\
\text { twin-pair } \\
\text { estimations; only } \\
\text { men included in the } \\
\text { analysis. }\end{array}$ & $\begin{array}{l}\text { Physical activity was positively } \\
\text { associated with long-term income. }\end{array}$ \\
\hline $\begin{array}{l}\text { Lechner and Sari } \\
\text { (2015) }\end{array}$ & $\begin{array}{l}\text { National Population Health } \\
\text { Survey }\end{array}$ & $\begin{array}{l}\text { Individual and } \\
\text { household }\end{array}$ & $\begin{array}{l}\text { Leisure-time physical } \\
\text { activity was divided into }\end{array}$ & $\begin{array}{l}\text { Semiparametric } \\
\text { matching estimation }\end{array}$ & $\begin{array}{l}\text { Positive earnings effect (10\% to } 20 \% \text { ) } \\
\text { was found, but no systematic effect }\end{array}$ \\
\hline
\end{tabular}

This article is protected by copyright. All rights reserved 


\begin{tabular}{|c|c|c|c|c|c|}
\hline & & $\begin{array}{l}\text { earnings, } \\
\text { employment } \\
\text { status, and } \\
\text { working hours }\end{array}$ & $\begin{array}{l}\text { three groups: moderately } \\
\text { active (daily energy } \\
\text { expenditure between } 1.5-3 \\
\mathrm{kcal} / \mathrm{kg} \text { ), active (daily energy } \\
\text { expenditure > } 3 \mathrm{kcal} / \mathrm{kg} \text { ), and } \\
\text { inactive (daily energy } \\
\text { expenditure }<1.5 \mathrm{kcal} / \mathrm{kg} \text { ). }\end{array}$ & & $\begin{array}{l}\text { on employment status or hours of } \\
\text { work was found. }\end{array}$ \\
\hline Kari et al. (2016) & $\begin{array}{l}\text { Young Finns Study, } \\
\text { Finnish Longitudinal } \\
\text { Employer-Employee Data }\end{array}$ & Annual earnings & $\begin{array}{l}\text { Childhood leisure-time } \\
\text { physical activity including } \\
\text { frequency and intensity of } \\
\text { physical activity, } \\
\text { participation in sports club } \\
\text { training sessions, } \\
\text { participation in sports } \\
\text { competitions, and the } \\
\text { habitual way of spending } \\
\text { leisure-time. }\end{array}$ & OLS & $\begin{array}{l}\text { Childhood physical activity was } \\
\text { positively associated with long-term } \\
\text { earnings among men. Among women, } \\
\text { no relation was observed. }\end{array}$ \\
\hline $\begin{array}{l}\text { Lechner and } \\
\text { Downward } \\
\text { (2017) }\end{array}$ & $\begin{array}{l}\text { Active People Survey } \\
\text { (APS), Annual Population } \\
\text { Survey (APopS), Active } \\
\text { Places Survey (APLS) }\end{array}$ & $\begin{array}{l}\text { Household } \\
\text { income, } \\
\text { employment, } \\
\text { unemployment, } \\
\text { and retirement }\end{array}$ & $\begin{array}{l}\text { Participation, frequency, and } \\
\text { the intensity of physical } \\
\text { activity aggregated into five } \\
\text { groups; team sports, keep fit } \\
\text { activities, racquet sports } \\
\text { leisure activities, and } \\
\text { outdoor activities. }\end{array}$ & $\begin{array}{l}\text { Propensity-score } \\
\text { radius matching } \\
\text { with regression } \\
\text { adjustment }\end{array}$ & $\begin{array}{l}\text { Sports participation was positively } \\
\text { associated with earnings. Association } \\
\text { was strongest for fitness and outdoor } \\
\text { sports. Sports participation was } \\
\text { negatively associated with } \\
\text { unemployment among men. Team } \\
\text { sports participation was positively }\end{array}$ \\
\hline
\end{tabular}

This article is protected by copyright. All rights reserved 
This article is protected by copyright. All rights reserved 
Appendix 2. The cohorts and the study design

\section{Data source}

\begin{tabular}{|c|c|c|c|c|c|c|c|c|}
\hline \multicolumn{5}{|c|}{ YFS } & \multicolumn{4}{|c|}{ FLEED } \\
\hline 1980 & 1983 & 1986 & 1989 & 1992 & 1997 & 2000 & 2005 & 2010 \\
\hline base- & follow & follow & follow & follow & & & & \\
\hline line & -up & -up & -up & -up & & & & \\
\hline 3 & 6 & 9 & 12 & 15 & 20 & 23 & 28 & 33 \\
\hline
\end{tabular}

Cohort 1

(born in 1977)

Cohort 2

$\begin{array}{lll}6 & 9 & 12\end{array}$

$15 \quad 18$

23

26

31

36

(born in 1974)

Cohort 3

$9 \quad 12$

15

18

21

26

$29 \quad 34$

39

(born in 1971)

Cohort 4

12

15

18

21

24

$29 \quad 32$

37

42

(born in 1968)

Cohort 5

15

18

21

24

27

$32 \quad 34$

40

45

(born in 1965)

Cohort 6

$\begin{array}{lll}18 & 21 & 24\end{array}$

$27 \quad 30$

35

38

43

48

(born in 1962)

Notes: YFS - Cardiovascular Risk in Young Finns Study; FLEED — Finnish Longitudinal Employer-Employee Data. YFS was launched in 1980, with follow-ups performed in 1983, 1986, 1989, 1992, 2001, 2007, and 2011. FLEED covers the period from 1997 to 2010. 
Appendix 3. The original scoring and recoding of physical activity index (PAI) in 1980-89, (range 5$14)$.

\begin{tabular}{lll}
\hline Items & Original Score & Code for PAI \\
\hline How often do you engage in & & \\
leisure-time physical activity at & & \\
least half an hour per time? & & 1 \\
Not at all & 1 & 1 \\
Less than once a month & 2 & 1 \\
Once a month & 3 & 1 \\
2-3 times a month & 4 & 2 \\
Once a week & 5 & 2 \\
2-6 times a week & 6 & 3 \\
Every day & 7 &
\end{tabular}

How much are you breath-

taking and sweating when you

engage in physical activity and

sport?

Not at all

Moderately

1

1

Lot of

3

How many times a week do you

usually engage in the training

sessions of sports club?

Not at all

Occasionally

1

Less than once a month

2 1

Once a month or more

3

1

Once a week

4

2

Many hours and times a week

5

2

6

3

Do you participate in regional or national level competitions?

No 
What do you usually do in your

\section{leisure time?}

I am usually indoors and read or 1

do something like that

I spend my time indoors and $\quad 2$

outdoors, outdoors I usually walk

or spend time with my friends.

I am usually outdoors and

exercise rather much.

This article is protected by copyright. All rights reserved 
Appendix 4. The original scoring and recoding of physical activity index (PAI) in 1992, (range 5-14).

\begin{tabular}{lll}
\hline Items & Original Score & Code for PAI
\end{tabular}

How much are you breath-

taking and sweating when you

engage in physical activity and

sport?

Not at all

Moderately

1

Lot of

2

2

How often do you engage in

intensive physical activity?

Not at all

1 1

Once a month or more

Once a week

2

2-3 times a week

2

4-6 times a week

2

Every day

How many hours a week do

you engage in intensive

physical activity?

Not at all

1

$1 / 2$ hour a week

1

1 hour a week

2

2-3 hours a week

2

4-6 hours a week

2

Over 7 hours a week

$6 \quad 3$

\section{How long time do you usually}

spend for physical activity

Less than $20 \mathrm{~min}$

20-40 min.

40-60 min. 
More than 60 min.

Are you a member of the sports club?

No

Yes

1

2

This article is protected by copyright. All rights reserved 
Appendix 7. Propensity score matching (PSM) estimation

We used a propensity-score-matching (PSM) estimator (command tteffects psmatch in STATA/MP 16.0) to estimate the average treatment effect on the treated (ATET). Here the estimators were based on estimating a probit model for the probability of belonging to a High PAI group (=treated) compared to a Low PAI group (=untreated), conditional on individual and family control variables. We used the same individual and family control variables as in the OLS models - that is, gender, birth cohort, birth month, child health, body fat, family income, parents' education, and family size. Children and adolescents were categorized into the High PAI group if their PAI $\geq 10$, and into the Low PAI group otherwise.

Table A.1 reports the PSM results. The sample size corresponds to the sample sizes reported in Table 3 of the manuscript - that is, at age 9, the sample size varied from 1385 to 1477; and at age 15, from 2136 to 2278 . In general, the results suggest that children with a higher physical activity level at ages 9 and 15 have more employment months and fewer unemployment months. For example, higher physical activity (High PAI) at age 15 is related to 0.4 more months of employment and 0.2 fewer months of unemployment during the years 2005-2010.

This article is protected by copyright. All rights reserved 
Table A.1 PSM estimation results to estimate the average treatment effect of childhood higher $(\mathrm{PAI} \geq 10)$ physical activity on employment and unemployment.

Average treatment effect on the treated (ATET)

Physical activity at age $9 \quad$ Physical activity at age 15

High PAI versus Low PAI

Average employment

months
$1997-2010$
$0.442 * *$
0.135
(0.222)
2005-2010
0.113
$0.408 * * *$
$(0.172)$

Average unemployment

months

1997-2010

$-0.057$

$-0.186 * *$

(0.118)

(0.075)

2005-2010

$-0.011$

$-0.221 * *$

(0.125)

(0.086)

Note: Robust Abadie-Imbends standard errors are in the parentheses. Children and adolescents were categorized into the High PAI groups when PAI $\geq 10$, and into the Low PAI group otherwise. The sample sizes correspond to the sample sizes reported in Table 3 of the manuscript.

There are at least two issues that must be discussed while interpreting the PSM results. First, conducting a robust matching analysis typically requires large sample sizes. In our case, the sample size varied from 1385 to 2278 , which might be too small to have robust results. If we were to used the pooled sample over the years, instead of a fixed sample size, the coefficients would remain intact, whereas the standard errors would become smaller (Table A.2).

This article is protected by copyright. All rights reserved 
Table A.2 PSM estimation results to estimate the average treatment effect of childhood higher (PAI $\geq 10)$ physical activity on employment and unemployment with unrestricted sample size.

Average treatment effect on the treated (ATET)

\section{Physical activity at age $9 \quad$ Physical activity at age 15}

High PAI versus Low PAI

Average employment

months

$1997-2010$

$0.442 * * *$

$0.135 * * *$

$(0.040)$

(0.038)

2005-2010

$0.113 * *$

$0.408 * * *$

(0.047)

Average unemployment

months

1997-2010

$-0.057 * *$

$-0.186^{* * *}$

(0.022)

(0.018)

2005-2010

$-0.011$

$-0.221 * * *$

(0.035)

(0.030)

Note: Robust Abadie-Imbends standard errors are in the parentheses. Children and adolescents were categorized into the High PAI groups when PAI $\geq 10$, and into the Low PAI group otherwise.

Second, the physical activity variable illustrates overall leisure-time physical activity not, for example, the proportion of children who achieve the recommended levels of physical activity for health, which could work as a good way to define the treatment. In our setting, however, the variable ranged from 5 (lowest level of physical activity) to 14 (highest level of physical activity). The subsamples within each value (5 to 14) are too small for robust matching analysis. Thus, we had to choose a cut-off point that illustrated children with higher physical activity (High PAI=treated) and lower physical activity (Low PAI=untreated). In our example, defining the treatment group made the comparison of the original OLS results to the PNS results impossible. Instead, the PNS results more likely give us confidence about the sign of the association between childhood physical activity and labor market outcomes - that 
is, higher childhood physical activity is positively related to employment months and negatively related to unemployment months. 
Appendix 8. OLS regressions results of physical activity index (PAI) at ages 9 and 15 and long-term labor market attachment adjusted with adulthood physical activity in 2001.

\begin{tabular}{|c|c|c|c|c|}
\hline & \multicolumn{2}{|c|}{$\begin{array}{l}\text { Average employment } \\
\text { months in } 2005-2010\end{array}$} & \multicolumn{2}{|c|}{$\begin{array}{l}\text { Average unemployment } \\
\text { months in 2005-2010 }\end{array}$} \\
\hline & 1 & 2 & 1 & 2 \\
\hline \multirow[t]{2}{*}{ PAI at 9 years } & 0.06 & 0.047 & -0.053 & -0.046 \\
\hline & $(0.041)$ & $(0.041)$ & $(0.030)$ & $(0.031)$ \\
\hline $\mathrm{R}^{2}$ & 0.06 & 0.07 & 0.03 & 0.04 \\
\hline $\mathrm{N}$ & 990 & 990 & 1019 & 1019 \\
\hline \multirow[t]{2}{*}{ PAI at 15 years } & $0.058 *$ & 0.047 & $-0.075^{* * *}$ & $-0.070 * * *$ \\
\hline & $(0.033)$ & $(0.035)$ & $(0.024)$ & $(0.024)$ \\
\hline $\mathrm{R}^{2}$ & 0.08 & 0.08 & 0.05 & 0.05 \\
\hline $\mathrm{N}$ & 841 & 841 & 867 & 867 \\
\hline \multicolumn{5}{|l|}{ Control variables } \\
\hline Cohort and birth month & $\mathrm{x}$ & $\mathrm{x}$ & $\mathrm{x}$ & $\mathrm{x}$ \\
\hline Individual characteristics & $\mathrm{x}$ & $\mathrm{x}$ & $\mathrm{x}$ & $\mathrm{x}$ \\
\hline Family characteristics & $\mathrm{x}$ & $\mathrm{x}$ & $\mathrm{x}$ & $\mathrm{x}$ \\
\hline $\begin{array}{l}\text { Adulthood physical activity } \\
\text { in } 2001\end{array}$ & & $\mathrm{x}$ & & $\mathrm{x}$ \\
\hline
\end{tabular}

Notes: Heteroscedasticity-robust standard errors are in parenthesis. Model 1 include controls for gender, cohort (1-5), birth month, summary of an individual's chronic conditions, body fat, family income, parent's education, and family size. Model 2 controls adulthood PAI obtained in 2001. Cohort dummies indicate the year of birth: Cohort 1 = born in 1977; Cohort $2=$ born in 1974; Cohort $3=$ born in 1971; Cohort 4 = born in 1968; and Cohort $5=$ born in $1965 . * * *$ Statistically significant at least at the $1 \%$ level.

This article is protected by copyright. All rights reserved 
Table 1 Mean characteristics of the samples

\begin{tabular}{lll} 
Study sample & Study sample & Source \\
$n=1565$ & $n=2445$ & \\
\hline Mean & Mean \\
(Std.) & (Std.)
\end{tabular}

Individual characteristics

$\begin{array}{llll}\text { Female } & 0.50 & 0.51 & \text { FLEED } \\ & (0.50) & (0.50) & \\ \text { Age (in 2010) } & 36.28 & 39.38 & \text { FLEED } \\ & (2.46) & (4.20) & \\ \text { Health endowments in } & 0.18 & 0.20 & \text { YFS } \\ 1980 & (0.38) & (0.40) & \text { YFS } \\ \text { Body fat }(\%) \text { in } 1980 & 14.81 & 16.43 & \end{array}$

Labor market attachment

Labor market participation

1997-2010

0.73

0.77

FLEED

$(0.28)$

$(0.28)$

2005-2010

0.83

0.84

FLEED

(0.30)

$(0.29)$

Employment months

1997-2010

9.01

9.52

FLEED

(2.77)

(2.78)

2005-2010

10.70

10.90

FLEED

(2.21)

(2.06)

Unemployment months

1997-2010

0.85

0.84

FLEED

(1.59)

(1.42)

2005-2010

0.67

0.61

FLEED

(1.59)

Physical activity index (PAI)

$\begin{array}{llll}\text { PAI at age } 9 & 9.39 & 9.39 & \text { YFS } \\ & (1.54) & (1.54) & \\ \text { PAI at age 15 } & 9.15 & 8.98 & \text { YFS }\end{array}$


Change in physical activity level from 9 to 15 years $(n=1257)$

Persistently active $\quad 0.12$

0.12

YFS

$(0.32)$

$(0.32)$

Increasingly active

0.22

0.22

YFS

$(0.42)$

$(0.42)$

Moderately active

0.17

0.17

YFS

(0.37)

(0.37)

Decreasingly active

0.33

0.33

YFS

$(0.47)$

(0.47)

Persistently inactive

0.16

0.16

YFS

(0.37)

(0.37)

Other variables obtained in 1980

Family income $(€)$

13132

LPC

(7394)

(7445)

Education high, Father 0.13

0.10

LPC

$(0.31)$

Education high,

0.09

0.08

LPC

Mother

$(0.28)$

(0.27)

Family size

4.36

4.46

YFS

(1.35)

(1.44)

Notes: YFS — Cardiovascular Risk in Young Finns Study; FLEED — Finnish Longitudinal

Employer-Employee Data; LPC — Longitudinal Population Census.

Body fat (\%) in 1980 is estimated using the Slaughter skinfold-thickness equation, which is based on sex, maturation, and skinfold thicknesses. 
Table 2 Childhood physical activity (PAI) at ages 9 and 15 and the probability of employment.

\begin{tabular}{|c|c|c|c|c|}
\hline & \multirow[t]{2}{*}{$\begin{array}{l}\text { Employment } \\
(1997-2010)\end{array}$} & & \multicolumn{2}{|c|}{$\begin{array}{l}\text { Employment } \\
(2005-2010)\end{array}$} \\
\hline & & \multicolumn{2}{|l|}{$\mathrm{ME}^{\mathrm{a}}$} & $\mathrm{ME}$ \\
\hline \multirow[t]{2}{*}{ PAI at 9 years } & $0.067 *$ & 0.005 & $0.096 * * *$ & 0.012 \\
\hline & $(0.041)$ & & $(0.033)$ & \\
\hline Pseudo $\mathrm{R}^{2}$ & 0.05 & & 0.04 & \\
\hline $\mathrm{N}$ & 1555 & & 1529 & \\
\hline \multirow[t]{2}{*}{ PAI at 15 years } & $0.045^{*}$ & 0.003 & $0.077 * * *$ & 0.009 \\
\hline & $(0.025)$ & & $(0.022)$ & \\
\hline Pseudo $\mathrm{R}^{2}$ & 0.03 & & 0.03 & \\
\hline $\mathrm{N}$ & 2427 & & 2386 & \\
\hline
\end{tabular}

Notes: Regressions are probits. The dependent variable is a binary variable indicating whether an individual is employed throughout the observational year. ME are the marginal effects calculated for the case of binary independent variables. All models include controls for cohort (1-5) and birth month. Cohort dummies indicate the year of birth: Cohort $1=$ born in 1977; Cohort $2=$ born in 1974; Cohort 3 = born in 1971; Cohort $4=$ born in 1968; and Cohort $5=$ born in 1965. Heteroscedasticityrobust standard errors are in parenthesis. *, *** Statistically significant at least at the $10 \%$ and $1 \%$ level, respectively. 
Table 3 OLS regressions results of physical activity index (PAI) at ages 9 and 15 and long-term labor market outcomes.

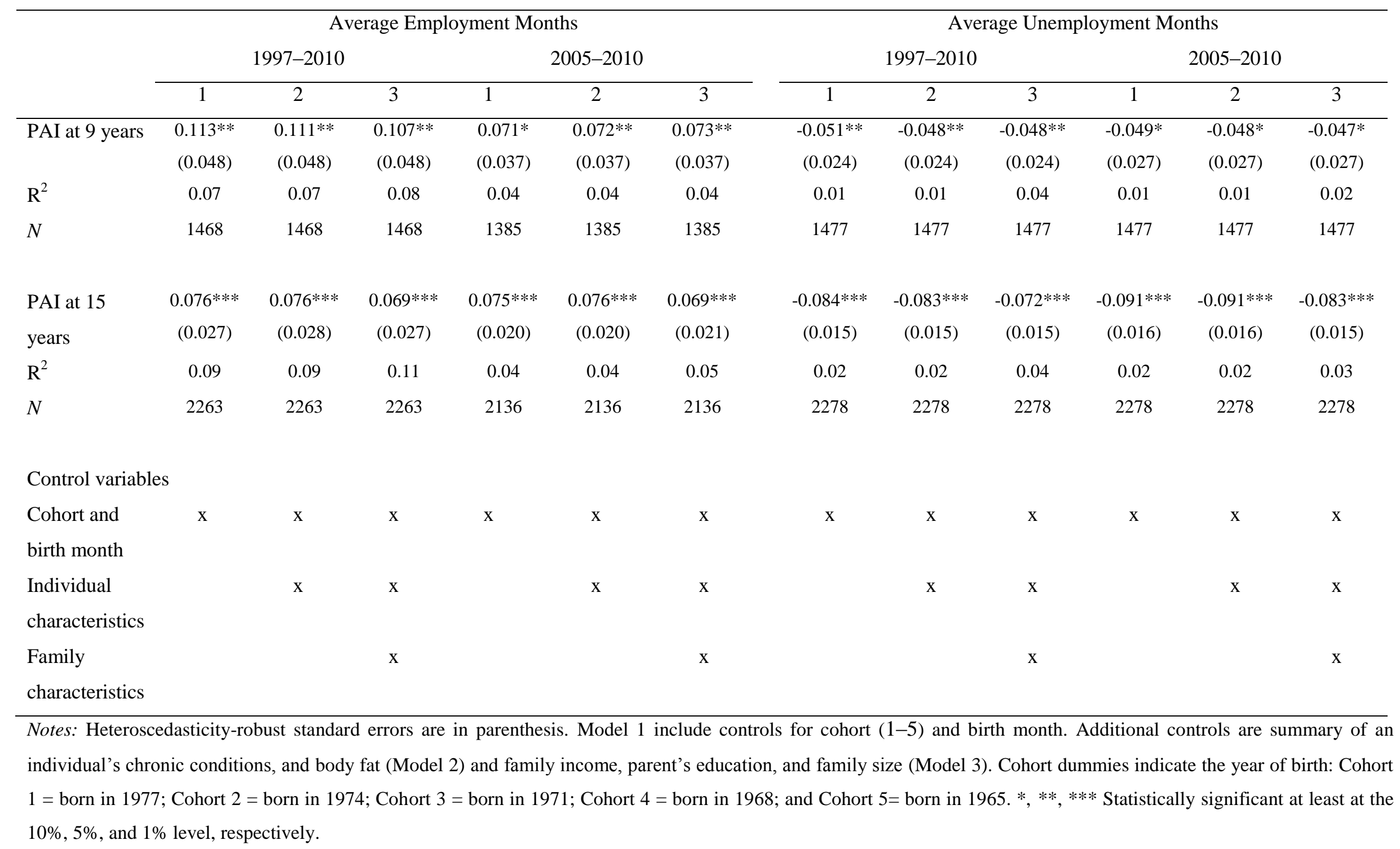

This article is protected by copyright. All rights reserved 
Table 4 Regression results of physical activity index (PAI) at ages 9 and 15 and long-term labor market attachment by gender.

\begin{tabular}{|c|c|c|c|c|c|c|c|c|c|c|c|c|}
\hline & \multicolumn{6}{|c|}{ Average Employment Months } & \multicolumn{6}{|c|}{ Average Unemployment Months } \\
\hline & \multicolumn{3}{|c|}{ 1997-2010 } & \multicolumn{3}{|c|}{ 2005-2010 } & \multicolumn{3}{|c|}{ 1997-2010 } & \multicolumn{3}{|c|}{$2005-2010$} \\
\hline & 1 & 2 & 3 & 1 & 2 & 3 & 1 & 2 & 3 & 1 & 2 & 3 \\
\hline \multicolumn{13}{|l|}{ Panel A: Women } \\
\hline \multirow[t]{2}{*}{ PAI at 9 years } & 0.150 & 0.012 & 0.026 & -0.070 & -0.067 & -0.056 & -0.028 & -0.025 & -0.027 & -0.0003 & -0.001 & -0.001 \\
\hline & $(0.074)$ & $(0.074)$ & $(0.073)$ & $(0.062)$ & $(0.062)$ & $(0.062)$ & $(0.028)$ & $(0.028)$ & $(0.028)$ & $(0.034)$ & $(0.035)$ & $(0.035)$ \\
\hline $\mathrm{R}^{2}$ & 0.04 & 0.04 & 0.06 & 0.02 & 0.02 & 0.03 & 0.02 & 0.03 & 0.06 & 0.02 & 0.02 & 0.03 \\
\hline$N$ & 739 & 739 & 739 & 691 & 691 & 691 & 742 & 742 & 742 & 742 & 742 & 742 \\
\hline \multirow[t]{2}{*}{ PAI at 15 years } & 0.039 & 0.040 & 0.034 & 0.033 & 0.034 & 0.016 & $-0.085 * * *$ & $-0.085^{* * *}$ & $-0.065 * * *$ & $-0.071 * * *$ & $-0.071 * * *$ & $-0.055 * * *$ \\
\hline & $(0.044)$ & $(0.044)$ & $(0.044)$ & $(0.034)$ & $(0.034)$ & $(0.035)$ & $(0.018)$ & $(0.018)$ & $(0.018)$ & $(0.021)$ & $(0.021)$ & $(0.021)$ \\
\hline $\mathrm{R}^{2}$ & 0.07 & 0.07 & 0.08 & 0.03 & 0.03 & 0.04 & 0.03 & 0.04 & 0.06 & 0.02 & 0.03 & 0.04 \\
\hline$N$ & 1179 & 1179 & 1179 & 1109 & 1109 & 1109 & 1184 & 1184 & 1184 & 1184 & 1184 & 1184 \\
\hline \multicolumn{13}{|l|}{ Panel B:Men } \\
\hline \multirow[t]{2}{*}{ PAI at 9 years } & $0.202 * * *$ & $0.201 * * *$ & $0.187 * * *$ & $0.188^{* * *}$ & $0.188 * * *$ & $0.184 * * *$ & $-0.072 *$ & $-0.069 *$ & $-0.069 *$ & $-0.081 * *$ & $-0.090 * *$ & $-0.089 * *$ \\
\hline & $(0.063)$ & $(0.064)$ & $(0.062)$ & $(0.045)$ & $(0.045)$ & $(0.044)$ & $(0.039)$ & $(0.039)$ & $(0.038)$ & $(0.041)$ & $(0.041)$ & $(0.040)$ \\
\hline $\mathrm{R}^{2}$ & 0.06 & 0.06 & 0.08 & 0.04 & 0.04 & 0.05 & 0.01 & 0.02 & 0.04 & 0.02 & 0.02 & 0.04 \\
\hline$N$ & 729 & 729 & 729 & 694 & 694 & 694 & 735 & 735 & 729 & 735 & 735 & 735 \\
\hline \multirow[t]{2}{*}{ PAI at 15 years } & $0.109 * * *$ & $0.108 * * *$ & $0.101 * * *$ & $0.106^{* * *}$ & $0.104 * * *$ & $0.103 * * *$ & $-0.083^{* * *}$ & $-0.083^{* * *}$ & $-0.078 * * *$ & $-0.105^{* * *}$ & $-0.106^{* * *}$ & $-0.103^{* * *}$ \\
\hline & $(0.035)$ & $(0.035)$ & $(0.035)$ & $(0.025)$ & $(0.025)$ & $(0.025)$ & $(0.022)$ & $(0.022)$ & $(0.022)$ & $(0.023)$ & $(0.023)$ & $(0.023)$ \\
\hline $\mathrm{R}^{2}$ & 0.08 & 0.08 & 0.10 & 0.03 & 0.03 & 0.04 & 0.03 & 0.03 & 0.05 & 0.03 & 0.03 & 0.04 \\
\hline$N$ & 1084 & 1084 & 1084 & 1027 & 1027 & 1027 & 1094 & 1094 & 1094 & 1094 & 1094 & 1094 \\
\hline \multicolumn{13}{|l|}{ Control variables } \\
\hline Cohort and & $\mathrm{x}$ & $\mathrm{x}$ & $\mathrm{x}$ & $\mathrm{x}$ & $\mathrm{x}$ & $\mathrm{x}$ & $\mathrm{x}$ & $\mathrm{x}$ & $\mathrm{x}$ & $\mathrm{x}$ & $\mathrm{x}$ & $\mathrm{x}$ \\
\hline
\end{tabular}

This article is protected by copyright. All rights reserved 
birth month

Individual

$\mathrm{x}$

characteristics

Family

Notes: Heteroscedasticity-robust standard errors are in parenthesis. Model 1 include controls for cohort (1-5) and birth month. Additional controls are summary of an individual's chronic conditions, and body fat (Model 2) and family income, parent's education, and family size (Model 3). Cohort dummies indicate the year of birth: Cohort $1=$ born in 1977; Cohort 2 = born in 1974; Cohort 3 = born in 1971; Cohort 4 = born in 1968; and Cohort 5= born in 1965. *,**, and *** Statistically significant at least at the $10 \%, 5 \%$, and $1 \%$ level, respectively.

This article is protected by copyright. All rights reserved 
Table 5 Long-term labor market outcomes by activity group

Panel 1 Long-term employment and unemployment months by activity group over the period from 1997 to 2010

\begin{tabular}{|c|c|c|c|}
\hline & $\%$-Share & $\begin{array}{l}\text { Average } \\
\text { Employment Months } \\
(1997-2010)\end{array}$ & $\begin{array}{l}\text { Average } \\
\text { Unemployment } \\
\text { Months } \\
(1997-2010)\end{array}$ \\
\hline Persistently active & 11.5 & 9.82 & 0.42 \\
\hline Increasingly active & 22.4 & 8.88 & 0.67 \\
\hline Moderately active & 16.6 & 9.10 & 0.75 \\
\hline Decreasingly active & 33.0 & 9.16 & 0.93 \\
\hline Persistently inactive & 16.5 & 8.76 & 0.94 \\
\hline F-test statistics & & $\begin{array}{l}3.76 \\
(p<0.01)\end{array}$ & $\begin{array}{l}4.97 \\
(p<0.01)\end{array}$ \\
\hline $\mathrm{N}$ & & 1251 & 1257 \\
\hline \multicolumn{4}{|c|}{$\begin{array}{l}\text { Panel } 2 \text { Long-term employ } \\
\text { period from } 2005 \text { to } 2010\end{array}$} \\
\hline & \%-Share & $\begin{array}{l}\text { Average } \\
\text { Employment Months } \\
(2005-2010)\end{array}$ & $\begin{array}{l}\text { Average } \\
\text { Unemployment } \\
\text { Months } \\
(2005-2010)\end{array}$ \\
\hline Persistently active & 12.0 & 11.31 & 0.28 \\
\hline Increasingly active & 22.2 & 10.70 & 0.54 \\
\hline Moderately active & 16.4 & 10.70 & 0.44 \\
\hline Decreasingly active & 33.1 & 10.64 & 0.76 \\
\hline Persistently inactive & 16.3 & 10.59 & 0.83 \\
\hline F-test statistics & & $\begin{array}{l}3.10 \\
(p=0.015)\end{array}$ & $\begin{array}{l}3.85 \\
(\mathrm{p}<0.01)\end{array}$ \\
\hline $\mathrm{N}$ & & 1183 & 1257 \\
\hline
\end{tabular}

This article is protected by copyright. All rights reserved 
Table 6 Long-term labor market attachment by activity group, Reference category: Persistently active.

\begin{tabular}{|c|c|c|c|c|c|c|c|c|}
\hline & \multicolumn{4}{|c|}{ Average Employment months } & \multicolumn{4}{|c|}{ Average Unemployment months } \\
\hline & \multicolumn{2}{|l|}{$1997-2010$} & \multicolumn{2}{|l|}{$2005-2010$} & \multicolumn{2}{|c|}{$1997-2010$} & \multicolumn{2}{|c|}{$2005-2010$} \\
\hline & 1 & 2 & 1 & 2 & 1 & 2 & 1 & 2 \\
\hline \multirow[t]{2}{*}{ Persistently inactive } & $-0.799 * * *$ & $-0.740 * * *$ & $-0.395^{*}$ & $-0.398 *$ & $0.572 * * *$ & $0.516 * * *$ & $0.515 * * *$ & $0.480 * * *$ \\
\hline & $(0.270)$ & $(0.270)$ & $(0.220)$ & $(0.218)$ & $(0.127)$ & $(0.123)$ & $(0.136)$ & $(0.134)$ \\
\hline \multirow[t]{2}{*}{ Decreasingly active } & $-0.652 * * *$ & $-0.617 * * *$ & $-0.519 * * *$ & $-0.512 * * *$ & $0.572 * * *$ & $0.520 * * *$ & $0.548 * * *$ & $0.520 * * *$ \\
\hline & $(0.217)$ & $(0.217)$ & $(0.177)$ & $(0.179)$ & $(0.105)$ & $(0.103)$ & $(0.108)$ & $(0.107)$ \\
\hline \multirow[t]{2}{*}{ Moderately active } & $-0.616 * *$ & $-0.600 * *$ & $-0.456 * *$ & $-0.458 * *$ & $0.361 * * *$ & $0.333 * * *$ & $0.290 * *$ & $0.283^{* *}$ \\
\hline & $(0.250)$ & $(0.250)$ & $(0.205)$ & $(0.207)$ & $(0.121)$ & $(0.120)$ & $(0.123)$ & $(0.124)$ \\
\hline \multirow[t]{2}{*}{ Increasingly active } & $-0.626 * * *$ & $-0.600 * *$ & $-0.436 * *$ & $-0.455 * *$ & $0.323 * * *$ & $0.336 * * *$ & $0.345^{* * *}$ & $0.360 * * *$ \\
\hline & $(0.236)$ & $(0.237)$ & $(0.185)$ & $(0.187)$ & $(0.098)$ & $(0.098)$ & $(0.103)$ & $(0.105)$ \\
\hline $\mathrm{N}$ & 1186 & 1186 & 1123 & 1123 & 1191 & 1191 & 1191 & 1191 \\
\hline \multicolumn{9}{|l|}{ Control Variables } \\
\hline Cohort and birth month & $\mathrm{x}$ & $\mathrm{x}$ & $\mathrm{x}$ & $\mathrm{x}$ & $\mathrm{x}$ & $\mathrm{x}$ & $\mathrm{x}$ & $\mathrm{x}$ \\
\hline $\begin{array}{l}\text { Individual and family } \\
\text { characteristics }\end{array}$ & & $\mathrm{x}$ & & $\mathrm{x}$ & & $\mathrm{x}$ & & $\mathrm{x}$ \\
\hline
\end{tabular}

Notes: Heteroscedasticity-robust standard errors are in parenthesis. Model 1 include controls for cohort (1-3) and birth month. Additional controls are summary of an individual's chronic conditions, body fat, family income, parent's education, and family size (Model 2). Cohort dummies indicate the year of birth: Cohort 1 = born in 1977; Cohort 2 = born in 1974; and Cohort 3 = born in 1971. *,**,*** Statistically significant at least at the $10 \%$, 5\%, and $1 \%$ level, respectively. Reference category: Persistently active.

This article is protected by copyright. All rights reserved 


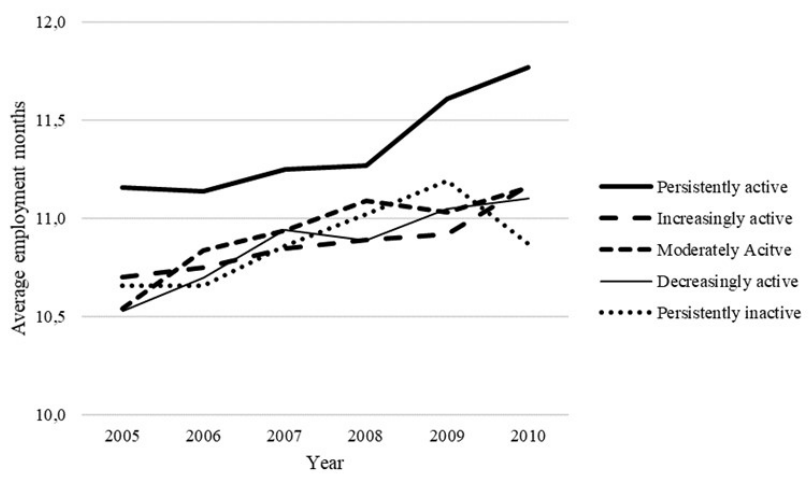

Figure 1. Average employment months by activity group over the period from 2005 to 2010 .

sms_13829_f1.jpg 


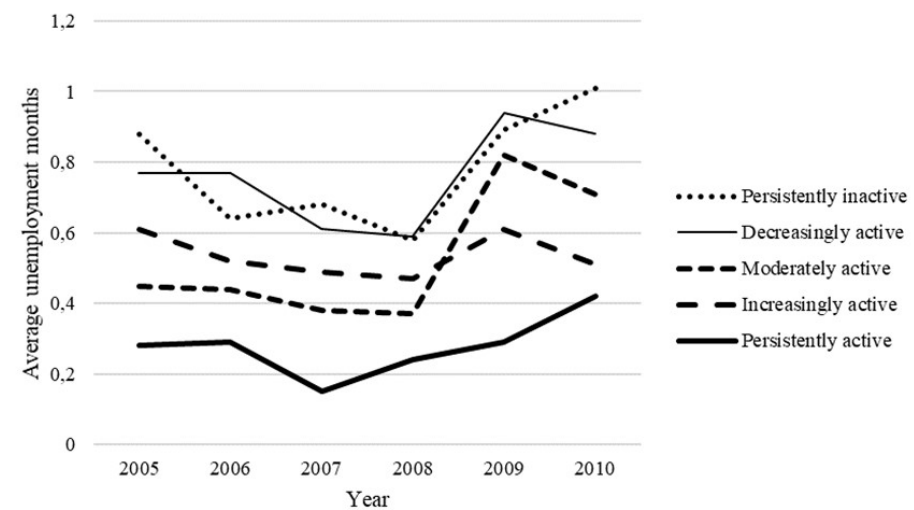

Figure 2. Average unemployment months by physical activity group over the period from 2005 to 2010 .

sms_13829_f2.jpg 